\title{
CIVIL LIABIITY AND THE SECURITIES ACT
}

\section{HARRY SHULMAN $\dagger$}

There is a danger in discussing civil liability in connection with the Securities Act that both the purpose of the Act and the emphasis of the discussion will be misunderstood. It is not the object of the Act simply to provide a legal remedy for the investor who has bought securities upon a false representation, to compensate him for a loss incurred. Even the provisions for civil liability are calculated to be largely preventive rather than redressive. Both in the extent of liability imposed - the variety of persons to whom the liability is attached, the bases of the liability, and the persons in whose favor it runs-and in the limitation of the amounts recoverable, the in terrorem function of the Act is evidenced. But even this purpose of securing preventive vigilance and caution on the part of the persons concerned is only coordinate with, or probably subordinate to, another object. The Act seeks not only to secure accuracy in the information that is volunteered to investors, but also, and perhaps more especially, to compel the disclosure of significant matters which were heretofore rarely, if ever, disclosed. Civil liability is imposed largely as one appropriate means of accomplishing these ends, not as the end itself, or, on the other hand, as the only means. While, then, discussion of the Act may properly be directed to the different provisions separately, it is apt to be misleading, and more covertly disingenuous, if the principal objectives are not constantly pushed to the front.

\section{I}

Apart from the Securities Act, the law does not condone misrepresentation in the sale of securities. Ideally, if not actually, misrepresentation entails possibilities of liability at common law intended to compensate investors and deter false statement. But the common-law liability was not consciously and especially moulded for the flotation of securities. Instead, general tort and contract law, developed largely in connection with other transactions, was applied piecemeal to securities cases as they came before the courts. In this process, indulgence was, of course, accorded to the mores of a developing business. The fortuitous incident of choice of remedy by plaintiff's counsel was frequently given major importance. A comprehensive underlying policy was rarely articulated.

†Associate Professor of Law, Yale University.

I have been aided by Miss Hilda Droshnicop, an editor of this Journal, who has done extensive research in the field of this article. 
And the process of fitting specific cases into generalized rule and remedy, developed largely for other situations, involved antithetical consequences. On the one hand, it glossed over differentiating circumstance, special feature or peculiar need, because of the fear of undue extension of liability generally. On the other hand, it succumbed to real differences of fact which had little bearing, however, on the policy underlying liability.

Deft pens have written the absorbing story of the protection accorded to purchasers and consumers of goods. ${ }^{1}$ Apart from the minimal requirements of weights and measures, pure food and similar legislation, ${ }^{2}$ the buyer's protection, both preventive and remedial, derives from judgemade law. In addition, the buyer derives some extra-legal protection as an incident of the competition for his dollars. Sales on approval or with the privilege to return, made for the purpose of overcoming the buyer's sales resistance or of gaining a talking point over competitors, and the custom of many merchants to accept the return of defective goods for the purpose of retaining the buyer's good will and trade, mitigate to some extent his risks in the market. ${ }^{3}$

The greatest adaptation in the shift of risks of purchase away from the buyer has taken place in the law of warranty. Upon the mere sale, the seller may now be held to a warranty to his buyer not only of his title, but also of the merchantable quality of the goods, or of their fitness for a particular purpose. ${ }^{4}$ With respect to defects causing physical injury, some courts have endowed the warranty concept with capacity to hurdle the forbidding notion of privity of contract in the endeavor to throw the loss directly upon the manufacturer of the product or the person dominant in the chain which brings the product to the consumer. The result is accomplished by implying an understanding between the parties to that effect-the familiar device of dressing coercive demands of law imposed for reasons of policy in the garb of voluntary assumption or mutual agreement. If legal taste and aesthetics were offended by the extension of warranty beyond the two parties to the sale, substantially similar results were achieved in the personal injury cases by purposeful use of the concepts of fraud and negligence, aided by the "presumption," res ipsa loquitur. ${ }^{5}$ And while the limitations imposed upon the seller's

1. Hamilton, The Ancient Maxim Caveat Emptor (1931) 40 YALE L. J. 1133; LLEweLIYN, Cases and Matertals on Sales (1930) 209; Radin, The Lawful Pursutr of Gano (1931) 47.

2. See Dunn, Food and Drug Laws (1927, Supp. 1929) ; Legis. (1931) 31 Cor. L. Rev. 872; Legis. (1932) 32 Coc. L. Rev. 720. For a story of present agitation with respect to proposed federal legislation, see Mitchell, Heap Bad Medicine (1933) 76 New Rep. 353.

3. See Bogert and Fink, Business Practice Regarding Warranties in the Sale of Goods (1930) 25 Irr. L. REv. 400, 415.

4. Uniforar Sales Act $\$ \S 13-16 ; 1$ Wirliston, Sales (1924) c. 9.

5. The story need not be developed here. When told, it is one of the best expositions 
exuberance in lauding his goods are few indeed, ${ }^{6}$ some bounds are indicated. It is said that warranties need not be made in any particular form, that any representations of fact by the seller inducing the sale may, under the circumstances of particular cases, be deemed warranties, with the consequent absolute liability upon the seller for losses caused as a result of their falsehood. ${ }^{7}$ In addition the buyer has several other remedies: a defense to an action by the seller on the contract of sale, rescission of the contract, or an action in tort for the damage caused by the misrepresentation.

Theoretically, the same law protects the buyer of securities. But a complex of factors, apart from the possibly different notions of policy with respect to the substantive questions of liability, have made the reality differ from the ideal. The seller of goods is engaged in the business of selling them. His capacity to bear the loss or even to prevent it is in many fields demonstrably greater than that of the buyer. The ultimate purchaser, the consumer, buys for immediate consumption or, in case of durable goods, for immediate use. With respect to a large and growing number of commodities, each purchase is more or less in direct response to the invitation and representations continuously advertised by the manufacturer or trade-name owner. A hidden defect in goods is generally quickly discovered when the goods are put to use. The mask is then removed, the harm is caused, and the life of the goods, as represented at least, is ended. The loss due to the original defect in the goods is comparatively readily ascertainable and distinguishable from losses due to price fluctuation or other factors. The defective commodity can be compared with the same commodity minus the defect - a real thing. Quite different, however, is the case of securities. The investor-seller is not engaged in the business of selling securities. A stock or bond is not continuously advertised by issuer, underwriter or distribution syndicate. While statements in prospectuses doubtless influence the market even after secondary distribution has ended, subsequent purchasers are, perhaps generally, not influenced consciously or

of the judicial process and the touted adaptability of the common law. See Bohlen, Liability of Manufacturers to Persons Other Than Their Immediate Vendees (1929) 45 L. Q. REv. 343; Note (1933) 33 Cox. L. Rev. 868; Note (1933) 18 CoRN. L. Q. 445; Note (1932) 7 Wasm. L. Rev. 351; Note (1932) 45 Harv. L. Rev. 1415; Note (1928) 42 Harv. L. REV. 414.

6. Cf. Handler, False and Deceptive Advertising (1929) 39 Yare L. J. 22.

7. Section 12 of the Uniform Sales Act provides that: "Any affirmation of fact or any promise by the seller relating to the goods is an express warranty if the natural tendency of such affirmation or promise is to induce the buyer to purchase the goods, and if the buyer purchases the goods relying thereon." For a general discussion of the development of the doctrine which this section codifies, see Williston, Representation and Warranty in Sales-Heilbut v. Buckleton (1913) 27 HaRv. L. Rev. 1; Bogert, Express Warranties in Sales of Goods (1923) 33 Yare L. J. 14. 
directly by such statements. 8 The security may pass from investor to investor with complete safety and cause a loss to a purchaser who was never aware of the representation which proved false or of the significant matter which was concealed. The original "defect" is seldom easily discoverable and more seldom quickly discoverable. Each issue of securities is unique. There is no "same security minus the defect" with which to make comparison. The fall in the value of the security, the loss to the investor, may be caused by innumerable factors of which the facts misrepresented or concealed at the time of the original issuance may truly be one. But whether or not they are a factor is frequently conjectural, and the exact amount of their influence on the fall, almost always conjectural. The original "defect" may never be discovered, therefore, because the fall in value may be attributed to a complex of other factors. And even when discovered, there remains the difficulty of connecting it with the loss. Given, then, even the same remedies available to purchasers of goods, the investor's burden of proof is not a happy one.

The law of warranty has had little application in the sale of securities. Only a warranty of title and that the stock or bond is a general security of the kind which it purports to be on its face is imposed on the seller by implication from the mere sale. No warranty is implied as to the quality or value or that the security was not issued in contravention of constitution, law or corporate charter. ${ }^{9}$ The buyer is held to have, and exercise, his own judgment as to value; and he is charged with knowledge of legal defects in the security. The liberality in treating representations in the sale of goods as warranties is absent in the security cases. Affirmations, no matter how positively made, are not warranties unless an intent to warrant is shown. ${ }^{10}$ There has not been any tendency to extend the reach of warranty to remote seller or issuer. And the doctrine seems not to differentiate between sales by individual investors and sales by dealers or issuers.

8. Indirectly, however, very effective influence may be exerted. Other buyers may know of the representation, rely upon it and thus create a larger demand for the security. The statement may get into a financial manual or periodical. It may there be reported directly or it may form the inarticulate foundation for an independent statement by the editors. Or the representation may influence the judgment of investment counsel or advisers upon whose opinions purchasers may rely.

9. See Uniform Stock Transfer Act $\$ 11$; Goodwyn v. Folds, 30 Ga. App. 204, 117 S. E. 335 (1923) ; Burwash v. Ballou, 230 Ill. 34, 82 N. E. 355 (1907).

10. Heilbut v. Buckleton, [1913] A. C. 30, discussed in Williston, supra note 7; Henderson v. Plymouth Oil Co., 13 F. (2d) 932 (W. D. Pa. 1926). The dearth of actions for breach of warranty in sales of securities is significant. While many cases say that the Uniform Sales Act is applicable to sales of securities [see Kaufman, Are Sales of Corporate Stock Subject to the Uniform Sales Act? (1932) 10 N. Y. U. . Q. Rev. 157; (1932) 32 CoL. L. REv. 547; (1932) 80 U. of PA. L. REv. 918], it seems impossible to find a case so holding with respect to Section 12 . 
Some elements of the law of warranty are found, however, in the law of rescission, when invoked by the buyer either defensively in the seller's action for breach of contract or offensively in the buyer's action for return of the purchase price. In rescission, as in warranty, it is said that the seller's wrong is sufficiently established when it is shown that he made a false representation about a material fact. It does not matter that the seller did not know of the falsity, that he did not intend to deceive, that he honestly believed in the truth of his statement, that he had very reasonable grounds for his belief. ${ }^{11}$ Nor does it matter that the falsity of the representation was not the cause of the fall in value. ${ }^{12}$ The object of the rescission being to restore the status quo ante the sale, it does not seem that a liability for loss is imposed upon the seller, or that money is being taken from his pocket to compensate the buyer. His position is not deemed to be unduly prejudiced if bets are declared off and each party returns to the other what he received in the sale.

But rescission can be invoked only against the buyer's immediate seller. It is available only to the person who buys from the misrepresentor. The investor who buys a security in the market, either directly on the strength of representations in a prospectus or circular or at a price in which such representations were obviously factors, cannot invoke this remedy either against his seller or the issuers of the prospectus or circular. ${ }^{13}$ And in the sale of securities, unlike the sale of goods, this limi-

11. No more than an illustrative case need be cited. As doctrine, the point is trite. That only lip service is paid to it in some cases is unquestionable. Occasionally, too, discrimination is made between rescission in equity and rescission at law, with the doctrine stated in the text confined to the former; and in some cases it is said that generally actual fraud must be shown. See 3 WrLISTON, Contracts (1920) $\S 1500 ; 2$ WIIIISTON, Sales (1924) § 632. See also, Farnsworth v. The Muscatine Produce \& Pure Ice Co., 161 Iowa 170,141 N. W. 940 (1913); Haebler v. Crawford, 258 N. Y. 130, 179 N. E. 319 (1932); Hill v. International Products Co., 129 Misc. 25, 220 N. Y. Supp. 711 (Sup. Ct. 1925) ; and cf. Henry v. Kopf, 104 Conn. 73, 131 Atl. 412 (1925); Moore v. Carrick, 26 Colo. App. 97, 140 Pac. 485 (1914); Whaley v. Niven, 175 Ark. 839, 1 S. W. (2d) 3 (1927). In. many cases rescission was sought after the defendant corporation became insolvent and was in the process of insolvency administration. The interest of creditors must have been some influence in the choice of language as well as results. $C f$. Stone v. Walker, 201 Ala. 130, 77 So. 554 (1917). Cf. note 15, infra.

12. See Seneca Wire \& Manufacturing Co. v. A. B. Leach \& Co., 247 N. Y. 1, 159 N. E. 700 (1928), where the false statement for which rescission was allowed was that application had been made to list the security on the New York Stock Exchange. Rescission was sought when the buyer learned that his stock was worthless because the corporation had gone into receivership. In a suit on the theory of rescission, it is commonly said, plaintiff need allege only that he relied on the representation, not that he suffered any loss thereby. Vulcan Fire Insurance Co. v. Jorgensen, 33 Cal. App. 763, 166 Pac. 835 (1917) ; Sheridan Oil Corp. v. Donaldson, 75 Colo. 584, 227 Pac. 553 (1924). But language to the contrary is also available.

13. He cannot rescind against the issuer of the statement because there is no contract or sale between them. Another remedy may, however, be available. Cf. Ritzwoller v. Lurie, 225 N. Y. 464, 122 N. E. 634 (1919). He cannot rescind against the seller, if, as we assume, 
tation excludes a large number of buyers. The corollary requirement that rescission effect a restoration of the status quo provides additional pitfalls: that the plaintiff did not or cannot return or tender to the seller the subject-matter of the sale,$^{14}$ that he did not act promptly and is guilty of laches, ${ }^{15}$ that he did something which may be taken as a ratification of the sale and as inconsistent with a desire to rescind. ${ }^{16}$ And, again, be-

the seller did not make, adopt or use the statement. There are, as may be expected, limitations even on this statement, but of not general importance in securities cases. See 2 WIIIISTON, SALES (1924) $\$ \S 636 \mathrm{a}, 636 \mathrm{~b}$.

14. In cases involving innocent misrepresentations, it has sometimes been said that rescission of an executed contract of sale will not be enforced, apparently because complete restoration of the status quo is not possible. The seller is deprived of the property and the opportunities to use or sell it while it was in the buyer's possession even if the identical property is returned to him. See Sedden v. North Eastern Salt Co., [1905] 1 Ch. Div. 326; Angel v. Jay, [1911] 1 K. B. 666. On the other hand, the plaintiff has been relieved of the obligation to tender return of the property where it has become entirely worthless or where complete return is impossible because of the defendant's conduct. Continental Jewelry Co. v. Pugh Brothers, 168 Ala. 295, 53 So. 324 (1910); Zang v. Adams, 23 Colo. 408, 48 Pac. 509 (1897); 2 WIIIIsToN, Sales (1924) § 610. "In exacting the return of benefits as a condition of rescission it [a court of equity] proportions the exaction to the justice of the case before it. . . . The wrongdoer will be left in the toils of his duplicity.'" Marr v. Tumulty, 256 N. Y. 15, 21, 175 N. E. 356, 357 (1931). And it may be that a buyer of securities who wishes to rescind after he has disposed of them may purchase like securities on the market and tender them. But query. See Mayo v. Knowlton, 134 N. Y. 250, 31 N. E. 985 (1892) ; Francis v. New York \& Brooklyn Elevated Rr. Co., 108 N. Y. 93, 15 N. E. 192 (1888); Note (1932) 4 (3) CoRP. PraC. REv. 62. For illustrations of the bother about restoration of status quo, see Edenborn v. Sim, 206 Fed. 275 (C. C. A. 2d, 1913); Jordan \& Davis v. Annex Corp., 109 Va. 625, 64 S. E. 1050 (1909); Franey v. Warner, 96 Wis. 222, 71 N. W. 81 (1897).

15. Since so many of the claims for rescission are made after the corporation has become insolvent, the finding of laches is probably frequently influenced by a desire not to give the complaining shareholder a preference over the remaining shareholders or an interest prejudicial to the corporation's creditors [cf. Webb v. Tri-State Fair \& Racing Association, $238 \mathrm{Ky} .87,36 \mathrm{~S}$. W. (2d) 839 (1931); Akers v. Radford State Bank, 153 Va. 1, 149 S. E. 528 (1929)] although it is said: "While the rule may be otherwise in England, in this country it is generally held that a defrauded shareholder may rescind after the insolvency of the corporation." MacNamee v. Bankers' Union For Foreign Commerce \& Finance, 25 F. (2d) 614,617 (C. C. A. 2d, 1928). The point of laches is rarely presented alone. Illustrative cases are Maginess v. Western Securties Corp., 38 Cal. App. 56, 175 Pac. 277 (1918); Marten v. Burns Wine Co., 99 Cal. 355, 33 Pac. 1107 (1893); Burwash v. Ballou, supra note 9; Fletcher American Co. v. Culbertson, $215 \mathrm{Ky} .695,286 \mathrm{~S}$. W. 84 (1926); Sarantides v. Williams, Belmont \& Co., 180 N. Y. Supp. 741 (Sup. Ct. 1920).

16. Retention of dividends, voting of the stock, attempts to sell the stock, payment of purchase price instalments, attempts to settle the disputed claim, if occurring after the buyer became aware of, or had reason to suspect, the falsity of the representations, may be considered as ratifications of the sale which make rescission thereafter unavailable. See Marten v. Burns Wine Co., supra note 15; Stockmen's Guaranty Loan Co. v. Sanchez, 26 N. M. 499, 194 Pac. 603 (1921) ; Brennan v. National Equitable Investment Co., 247 N. Y. 486, 160 N. E. 924 (1928); Buker v. Leighton Lea Association, 63 App. Div. 507, 71 N. Y. Supp. 610 (4th Dep't 1901); Davis v. Gifford, 182 App. Div. 99, 169 N. Y. Supp. 492 
cause of differences already mentioned, these limitations are much more exclusive in the case of securities than in the case of commodities. But even after the buyer has negotiated the slippery rungs of this ladder, he is yet unable to reach the seller unless the ladder is placed on the foundation that the seller misrepresented a material fact upon the truth of which the buyer relied. What is fact as distinguished from opinion, what is material as distinguished from trivial, what is reliance as distinguished from indifference, are questions which are raised also in connection with other remedies and will be discussed below. The answers lie largely in individual choice or judgment. The foundation may thus be difficult or easy to find. In the case of securities it has not been more easy than difficult.

There remain the tort actions of deceit and negligence. Much has been written about these actions and the basis of liability for misrepresentation. ${ }^{17}$ The older action of deceit, true to its name, was a remedy for villainy. Hornbook has it that the "elements" of the action are that the defendant made a representation of fact which was false, that the defendant knew of the falsity but nevertheless made the statement for the purpose of inducing the plaintiff to rely thereon, that the plaintiff did rely thereon and suffered damage as a consequence. ${ }^{18}$ Literally, the charge is a very serious one. It is, in effect, an accusation of thievery, of procuring money under false pretenses. When gentlemen respected in the business community were sued in deceit for a false statement in a prospectus, ${ }^{10}$ the House of Lords balked at the idea of convicting them of so serious a charge. The remedy appropriate against deceitful rogues was not to be applied to respectable business men who believed their statements to be true, however unreasonably that belief was founded. The charge against the defendants was couched in terms appropriate for a criminal prosecution. Deceit might be a crime. The limitations of the criminal law for the protection of the accused could be borrowed, therefore, almost unconsciously, for the protection of the defendants in the tort

(1st Dep't 1918) ; Corporation Funding \& Finance Co. v. Stoffregen, 264 Pa. 215, 107 Atl. 727 (1919); Biel v. Union Fuel \& Ice Co., 105 Wash. 41, 177 Pac. 813 (1919). What is said in notes 11 and 15 , supra, is, of course, also applicable here.

17. It would be complete supererogation to attempt exhaustive citation of cases for what follows. The cases have several times been collected in the numerous discussions of the problem. See Smith, Liability for Negligent Language (1900) 14 HARv. I. REv. 184; Williston, Liability for Honest Misrepresentation (1911) 24 HARv. L. Rev. 415; Bohlen, Misrepresentation as Deceit, Negligence, or Warranty (1929) 42 HARv. I. REv. 733 ; Green, Deceit (1930) 16 VA. L. REv. 749 [reprinted in GREEN, JUDGE AND JURY (1930) 280]; Carpenter, Responsibility for Intentional, Negligent and Innocent Misrepresentation (1930) 24 ILL. L. REv. 749; Weisiger, Basis of Liability for Misrepresentation (1930) 24 ILL. L. REv. 866; Bohlen, Should Negligent Misrepresentations Be Treated As Negligence Or Fraud? (1932) 18 VA. L. REv. 703; Note (1931) 31 CoL. L. Rev. 858.

18. See HARPER, Torrs (1933) §§ 76, 221, 222 ; Green, supra note 17.

19. Derry v. Peek, 14 App. Cas. 337 (1889). 
action. $^{20}$ But the decision went beyond the mere form of remedy. The objection was not directed simply to the uncouth company in which the defendants would be placed if the deceit action against them were successful. As it soon became apparent, the decision was a ruling on the substantive question of liability, whatever the form of remedy; there was no redress for pecuniary loss suffered as a result of a misrepresentation honestly, though negligently, made. ${ }^{21}$ Judgment on the substantive question was happily made easier, however, by the plaintiff's allegation of his plaint in a form moulded for the dishonest rogue.

The "element" of knowledge by the defendant of the falsity of his statement was subjected to considerable variation. A number of substitutes were developed, particularly in the American cases and in Derry v. Peek ${ }^{22}$ itself. The requirement of scienter is satisfied, it is variously said, if (1) the defendant knew of the falsity of the statement, or (2) did not believe in its truth, or (3) made it recklessly, careless whether it be true or false, or (4) the defendant made the statement as of knowledge when he knew he had no knowledge of its truth, regardless of his belief, provided that the statement is of a matter susceptible of knowledge, or (5) the defendant was in a special position to have knowledge of the truth of the statement and the plaintiff had no means of knowing, or (6) the defendant, though innocent of falsehood, had not made a reasonable investigation and had no reasonable grounds for the belief in the truth of his statement. ${ }^{23}$ The latter formula thus disposes of the element of scienter and substitutes negligence. An unintended honest lie is, then, in some cases held sufficient to ground an action in deceit which is also the remedy for the palpable, deliberate fraud. Other cases have preserved the integrity of the deceit doctrine and have recognized the negligence action as the appropriate remedy for redress of losses suffered as a

20. Thus Lord Halsbury: "Nevertheless, if, as I have said, the facts are reconcilable with the innocence of the directors, and with the absence of the mens rea which I consider an essential condition of an action for deceit, the mere fact of the inaccuracy of the statement ought not to be pressed into constituting a liability which appears to me not to exist according to the law of England." Id. at 344. Thus, too, Lord Bramwell: "I am glad to come to this conclusion; for, as far as my judgment goes, it exonerates five men of good character and conduct from a charge of fraud, which, with all submission, I think wholly unfounded, a charge supported on such materials as to make all character precarious." Id. at 345. And Lord Herschell: "The prospectus was therefore inaccurate. But that is not the question ... I cannot hold it proved as to any one of them [defendants] that he knowingly made a false statement, or one which he did not believe to be true... In short, I think they honestly believed that what they asserted was true, and I am of opinion that the charge of fraud made against them has not been established." Id. at 379 .

21. LeLievre and Dennes v. Gould, [1893] 1 Q. B. 491. See Note (1931) 31 Cor. L. REv. 858,860, n. 7.

22. Supra note 19.

23. See Green, supra note 17. 
result of honest lying, if remedy is available at all. ${ }^{24}$ The variation in the definition of the scienter requirement, particularly in admitting negligence as a sufficient substitute, has been denounced as confusing and misleading. False analogy is made plausible, proper decision in accordance with underlying policy rendered difficult, and the application of incorrect or inappropriate rules and defenses made apt, it is said, if clear discrimination is not drawn between liability for intended wrongs, liability for wrongs of negligence and absolute liability unconnected with fault or wrongdoing. On this analysis, it is urged, deceit should properly $\cdot$ be confined to cases of intentional lying, negligence to cases of unintended misrepresentation and warranty to cases where absolute liability is imposed. ${ }^{25}$ On the other hand, this "confusion" in definition of the scienter requirement in deceit has been applauded for the flexibility which it permits in reaching and articulating judgment on the basis of the circumstances in particular cases. The vagueness and variety is commended precisely because exercise of judgment on specific circumstances is not hampered by dogma or concept. ${ }^{26}$ This conflict of views relates not to the substantive questions of liability, not to the question of where the loss shall be put, but to the method by which the problem is to be posed for consideration, to the channels in which thought is to be directed. But while the controversy provides basis for much argument, it is not of great import here. If the action of deceit is limited to redress for false statements knowingly made (whether or not we assume that defendant's knowledge is generally susceptible of proof) and no remedy is provided for loss suffered as a result of honest misrepresentation, the investor's chances of recovery are seriously curtailed. But even where remedy is provided for honest misrepresentation, whether by enlargement of the deceit formula or by way of a negligence action, it is still apparent that liability in any particular case is entirely dependent upon the variable judgments of men-trial judge, jurors and appellate judges. Even when the language of the law, in such cases, is definite and peremptory, the reality of decision is unknown until these men have announced their choice. And in the past, this choice has not been very severe on those whose statements in prospectuses proved to be false.

Whatever instruction is provided by the law on the element of scienter, determination of other issues is required before the question of liability is to be answered. It must be determined, the law teaches, whether the representation was one of fact or merely of opinion, and if of fact, whether it was of a material fact, and, if of a material fact, whether the plaintiff

24. Compare Uttramares Corp. v. Touche, Niven \& Co., 225 N. Y. 170, 174 N. E. 441 (1931), with Glanzer v. Shepard, 233 N. Y. 236, 135 N. E. 275 (1922); and see International Products Co. v. Erie Rr. Co., 244 N. Y. 331, 155 N. E. 662 (1927).

25. Bohlen, supra note 17; HARPER, op. cit. supra note 18. Cf. Williston, supra note 17.

26. Green, supra note 17. 
did indeed rely upon the representation. For, if the plaintiff actually did not rely upon the representation, ${ }^{27}$ or, even though he did rely upon it, if the representation did not relate to anything which was a material factor in the purchase, ${ }^{28}$ or, even given both materiality and reliance, if the representation related not to a matter of fact but to one of opinion, ${ }^{20}$ inexorable law requires judgment for the defendant, whether he be an honest or a dishonest liar. The reasons advanced seem eminently reasonable. If the plaintiff did not rely upon the defendant's statement, or if the statement was about an immaterial fact, the plaintiff did not suffer because of the misrepresentation. For his lie the defendant's soul may have to suffer; but since he did not cause pecuniary loss, his pocketbook is immune. Likewise with respect to the issue of fact or opinion. Sellers are expected to be enthusiastic about their wares and to have exaggerated opinions about them, particularly in the course of a sale. Buyers, that is, reasonable buyers, know this and put no stock in sellers' talk and sellers' opinions. If a buyer relies on an opinion expressed by a seller, he is a fool and has his own folly, not the seller's deceitfulness, to blame for his loss. ${ }^{30}$ Reasonable men may differ as to what is a statement of fact and what of opinion. But the law is clear.

The law is clear, but it is not always fact. Statements as to legal matters, it has been held, are statements of opinion, since no one knows with certainty what decision will be made by a court before the court makes it. If this is too realistic and it is insisted that law must be fact because everyone is presumed to know the law, then the buyer knows it as well as the seller and therefore knows when the seller is misrepresenting it and when the representation should not be believed. ${ }^{31}$ At any

27. See, e. g., Parnes v. Gnome Manufacturing Co., 93 N. J. Eq. 470, 117 Atl. 148 (1922); Walker v. Mobile \& Ohio Rr. Co., 34 Miss. 245 (1857); Green, supra note 17; and the cases cited in note 28 , infra.

28. See, e. g., National Leather Co. v. Roberts, 221 Fed. 922 (C. C. A. 6th, 1915); American Building \& Loan Association v. Bear, 48 Neb. 455, 67 N. W. 500 (1896).

29. See cases cited in notes $31-43$, infra.

30. See Holmes, J., in Deming v. Darling, 148 Mass. 504, 505, 20 N. E. 107, 108 (1859): "The language of some cases certainly seems to suggest that bad faith might make a seller liable for what are known as 'seller's statements,' apart from any other conduct by which the buyer is fraudulently induced to forbear inquiries . . . But this is a mistake. It is settled that the law does not exact good faith from a seller in those vague commendations of his wares which manifestly are open to difference of opinion,-which do not imply untrue assertions concerning matters of direct observations, ... and as to which 'it has always been understood, the world over, that such statements are to be distrusted' ..." And see Bragg v. Kirksville Farmers Packing \& Warehouse Co., 205 Mo. App. $600,608,226$ S. W. 1012, 1015 (1920): “. . . men, as far back as we know anything of them, have ever understood that it was unsafe to trust to the opinion of the seller as to the worth and virtue of his own property. And nothing is more commonly understood thán that a vendee ordinarily does not and should not rely on the statements of his vendor when he makes a statement of the value of his property."

31. See notes 32-34, infra; and Note (1932) 32 Cor. L. REv. 1018, in which the cases are collected and well analyzed. 
rate statements to the effect that certain stock is non-assessable, ${ }^{32}$ or that, under its charter and applicable law, the corporation is empowered to do certain things, ${ }^{33}$ have been held by some courts to be not actionable because they were opinions on legal problems. In other cases, however, false statements on legal matters were held actionable if the other elements of a cause of action were made out. ${ }^{34}$ Statements as to value are the preeminent illustrations of non-actionable representations of opinion, ${ }^{35}$ although here, too, it has been held that, under some circumstances, the statements were more of fact and less of opinion and consequently actionable. $^{30}$ Non-actionable also are forecasts or statements as to future conduct. Since they look to the future they are not representations of fact. Non-actionable, therefore, were held statements to the effect that certain dividends would be earned or paid; ${ }^{37}$ that the stock would be worth a stated amount in a given time; ${ }^{38}$ that the proceeds of the issue would be applied to particular objects $;^{39}$ that a stated amount of assets would be maintained for the benefit of the preferred stockholders; ${ }^{40}$ and similar statements as to future events. ${ }^{41}$ In other cases the courts were apparently able to delve into the defendant's state of mind at the time he made the representation and found that it did not include an intention to live up to the representations at the appointed time, or that it did not entertain an opinion of the kind expressed. They regarded the statements, then, not as forecasts, promises or opinions, but as misrepresentations of

32. Rogan v. Illinois Trust and Savings Bank, 93 Ill. App. 39 (1901). Cf. Browne v. San Gabriel River Rock Co., 22 Cal. App. 682, 136 Pac. 542 (1913); Cooper v. Empire Security Co., 227 III. App. 161 (1922); Van Slochem v. Villard, 207 N. Y. 587, 101 N. E. 467 (1913).

33. Russel v. Alabama Midland Ry. Co., 94 Ga. 510, 20 S. E. 350 (1894).

34. Merchants Realty \& Investment Co. v. Kelso, 46 Cal. App. 218, 189 Pac. 116 (1920); and see Note (1932) 32 CoL. L. REv. 1018.

35. See note 30, supra; Matthews v. Hogueland, 98 Kan. 342, 157 Pac. 1179 (1916); and cases collected in Note (1931) 71 A. L. R. 622.

36. Antognini v. Grandi Co., 89 Cal. App. 628, 265 Pac. 378 (1928); Fourth National Bank v. Webb, 131 Kan. 167, 290 Pac. 1 (1930); McDonald v. Lastinger, 214 S. W. 829 (Tex. Civ. App. 1919); Note (1927) 13 CorN. I. Q. 140.

37. Zeh v. Alameda Community Hotel Corp., 122 Cal. App. 366, 10 P. (2d) 190 (1932); Farmers' Loan \& Mortgage Co. v. Langley, 166 La. 251, 117 So. 137 (1928); Stalnaker v. Jones, 68 W. Va. 176, 69 S. E. 651 (1910).

38. Huffistetler v. Our Home Life Insurance Co., 67 Fla. 324, 65 So. 1 (1914); Kimmel v. Eastern Coal \& Mining Co., 97 W. Va. 154, 124 S. E. 661 (1924). Cf. Cuckovich v. Buckovitch, 82 Mont. 1, 264 Pac. 930 (1928).

39. City National Bank v. Mason, 192 Iowa 1048, 186 N. W. 30 (1922); Field v. Seubert Bearing Co., 179 App. Div. 780, 167 N. Y. Supp. 294 (1st Dep't 1917); Milwaukee Brick \& Cement Co. v. Schoknecht, 108 Wis. 457, 84 N. W. 838 (1901).

40. Mandelbaum v. Goodyear Tire \& Rubber Co., 6 F. (2d) 818 (C. C. A. 8th, 1925).

41. Farwell v. Colonial Trust Co., 147 Fed. 480 (C. C. A. 8th, 1906); Chambers v. Mitchell, 123 II. App. 595 (1905); Lowry National Bank v. Hazard, 223 Pa. 520, 72 Atl. 889 (1909). 
the defendant's present intention, of his present state of mind-a fact $t^{42}$ Or they found the prediction so related to existing or past facts that it was to be interpreted as a representation of fact..$^{43}$

If it now seems difficult to make the simple differentiation between fact and opinion, it is frequently quite as difficult to make the still simpler determination whether the statement of fact is true or false. Is it false when, though literally true, it conveys a different impression to the reasonable reader; when it is true so far as it goes but is misleading because it omits mention of pertinent qualifications, because it is a half-truth; when it is ambiguous, false when taken in one sense, true when taken in another? ${ }^{44}$

Probably few of the initiate believe that a jury or even a court covers all this territory painstakingly in every case. But here is an arsenal of defensive doctrines available to defendants and courts. The plaintiff's entire offensive is vulnerable to any one of the doctrines. And any one of them, as has been seen, may be chosen to support a personal, human judgment. Regardless of the clarity of the instructional law, that judgment, on issues relating so largely to mental state and psychological effect and so little susceptible of indisputable proof, can be thrown either way. The results may be harsh or favorable to plaintiffs or defendants. In the past, they have not been unduly favorable to the plaintiffs. Most of the litigation has involved comparatively petty security issues and sales. And those engaged in the business of issuing securities have not failed to gird themselves for the use of any of the weapons available in this arsenal. Circulars and prospectuses are carefully prepared. In so far as possible, the statements are commonly made on the authority of others and in terms of opinion, belief or prediction, with the warning for good measure that "The statements contained in this circular, while not guaranteed, are obtained from sources which we believe to be reliable." ${ }^{\prime 4}$

But underlying the above discussion, as a foundation without which no part of the superstructure can be raised, is the legal issue of the reach of the defendant's duty. Both in negligence and in deceit, the issue as to whether or not the defendant owed any duty to the particular plaintiff

42. Electric Hammer Corp. v. Deddens, 206 Ky. 232, 267 S. W. 207 (1924); Faust v. Parker, 204 Iowa 297, 213 N. W. 794 (1927) ; Farmers' Co-Operative Grain Co. v. Startzer, 112 Neb. 19, 198 N. W. 170 (1924).

43. See Green, supra note 17 .

44. See Hotaling v. A. B. Leach \& Co., 126 Misc. 845, 214 N. Y. Supp. 452 (Mun. Ct. 1926), aff'd, 247 N. Y. 84, 159 N. E. 870 (1928); MacIntyre, Criminal Provisions of the Securities Act and Analogies to Similar Criminal Statutes (1933) 43 Yale 254; Note (1932) 45 HARv. L. Rev. 1078.

45. As to the effectiveness of such clauses, see Krause v. Cook, 144 Mich. 365, $10 \mathrm{~S}$ N. W. 81 (1906); Duryea v. Zimmerman, 121 App. Div. 560, 106 N. Y. Supp. 237 (2d Dep't 1907); Churchill v. St. George Development Co., 174 App. Div. 1, 160 N. Y. Supp. 357 (4th Dep't 1916); Continental Insurance Co. v. Equitable Trust Co., 127 Misc. 45, 215 N. Y. Supp. 281 (Sup. Ct. 1926); Note (1927) 75 U. of PA. L. Rev. 660. 
with respect to the representations is primary. And just as in the cases of warranty or rescission, that issue has insulated a large class of persons involved on the seller's side in the sale of securities against misrepresentation suits by a large class of investors. Lack of privity, here as in warranty or rescission, is the verbal insulating matter. The deceit action is maintainable, we are told, only by one to whom, or to influence whom, the representation is made. A purchaser of securities on the exchange, who had not read the prospectus, may not sue in deceit for a false statement therein because it was not an inducing factor in his purchase, even though it was a factor in the market valuation at which be bought. He may not maintain the action even if he had read and was influenced by the prospectus, because, it is said, the prospectus is addressed only to the initial buyers of the security and not to remote buyers in whose purchases the prospectus issuer has no interest. ${ }^{46}$ The ambit of duty could, of course, be extended, particularly in the negligence action where foreseeability of harm is a traditional measure. But, in securities cases, it has not been so extended.

Even as to the initial purchasers, similar restrictions limit the number of persons involved in the prospectus who may be subjected to liability if the burden of proof outlined above is sustained. The first limitation is, again, the notion of privity. Experts, accountants, lawyers, engineers, appraisers, whose reports are quoted in prospectus or circular, are deemed not subject to liability even to initial purchasers, unless willful misconduct is proved. ${ }^{47}$ They are, it is said, only employees, in effect, engaged to perform specific tasks. They receive compensation for their services, not for the assumption of risks of liability in indeterminate amounts to unknown persons who might suffer unintended loss because of some neglect in the performance of those tasks. Their duty to render

46. Cheney v. Dickinson, 172 Fed. 109 (C. C. A. 7th, 1909) ; Hunnewell v. Duxbury, 154 Mass. 286, 28 N. E. 267 (1891); Dinsmore v. National Hardwood Co., 234 Mich. 436, 208 N. W. 701 (1926); Brackett v. Griswold, 112 N. Y. 454, 20 N. E. 376 (1889); Greene v. The Mercantile Trust Co., 60 Misc. 189, 111 N. Y. Supp. 802 (Sup. Ct. 1908); Nicol's Case, 3 De G. \& J. 387, 438 (1859); Peek v. Gurney, L. R. 6 H. L. 377 (1873). But cf. Gerner v. Mosher, 58 Neb. 135, 78 N. W. 384 (1899); Houston v. Thornton, 122 N. C. 365, 29 S. E. 827 (1898); and see Berle, Liability for Stock Market Manipulation (1931) 31 CoL. L. REv. 264.

47. There seems to be no case in which a purchaser of securities has brought suit against such an expert for false statements in his reports quoted in a prospectus. But there have been many cases in which credit was extended, property bought or other action taken by plaintiffs in reliance upon similar reports made to third persons. The recent case of Ultramares Corp. v. Touche, Niven \& Co., supra note 24 (suit against firm of accountants which prepared a balance sheet on the faith of which the plaintiff advanced credit), attracted wide attention. Chief Judge Cardozo's opinion for the court makes a thorough and exhaustive analysis of precedent. Cases dealing with other experts are collected in the many comments on the Touche, Niven case. See Note (1930) 30 Cor.'X. Rev. 1066; Note (1930) 44 Harv. L. Rev. 134; Note (1930) 40 Yare L. J. 128; Note (1931) 31 Cor. L. Rev. 858. 
careful service and commit no negligence arises out of the contract by which they are employed and is owed to their employers. To others they owe only the duty not to make knowingly false statements. The risks of loss to persons other than their employers, attendant upon errors unknowingly committed by such experts, is to be shifted, if at all, to the business which the experts are employed to serve and which derives the profits from the enterprise to which their service is incidental. Sufficient deterrence against negligence in the performance of their services is provided by the threat of liability to their employers, by hope of further employment, and by desire for professional standing. Unlimited liability to persons beyond the contract, if reason therefor exists, must be imposed by the legislatures, not the courts. So runs the argument.

A related, and similarly justified, principle of limitation is that liability should be imposed for the consequences of one's own misconduct, not vicariously for the misconduct of others. Denial of recovery to a plaintiff may, then, be rested upon a finding that the defendant did not personally participate in the misrepresentation. The defendant may have been an inactive director in the company which issued the statement. He may have lent his name simply to adorn the board without undertaking or being asked to undertake any duties of supervision. Or he may have become a director for the purpose of advising on limited, specific phases of the company's business. Or he may have suited his own whim or convenience in his attention to company matters, attending to some and ignoring others. If, for whatever reason, the director took no part in the preparation, ratification or issuance of the false statement or circular, he is not liable, it has been held, to purchasers who acted on the faith of the statement. ${ }^{48} \mathrm{He}$ has done nothing. And he is not to be held vicariously for the fraud or negligence of others, co-directors, executives or underwriters, unless he has constituted them his "agents." 40 It may be urged, as it has been held in other connections, ${ }^{50}$ that the director is not sought to be held liable vicariously for another's tort, but directly for his own neglect properly to perform the duties of his office; that by consenting to be named a director he comes under certain affirmative obligations imposed by law which he must discharge at the pain of liability for his neglect; that the liability imposed is for his own disregard of

48. Gerner v. Mosher, supra note 46; Rives v. Bartlett, 215 N. Y. 33, 109 N. E. 83 (1915) ; Arthur v. Griswold, 55 N. Y. 400 (1874); Ottman v. Blaugas Co. of Cuba, 17l App. Div. 197, 157 N. Y. Supp. 413 (1st Dep't 1916) ; McFarland v. Carlsbad Sanitarium Co., 68 Ore. 530, 137 Pac. 209 (1913); Sugarland Industries v. Parker, 293 S. W. 609 (Tex. Civ. App. 1927).

49. See Downey v. Finucane, 205 N. Y. 251, 98 N. E. 391 (1912)), as explained in Rives v. Bartlett, supra note 48.

50. Cf. Chapple v. Jacobsen, 234 Mich. 558, 208 N. W. 754 (1926) ; Solomon v. Bates, 118 N. C. $311,321,24$ S. E. 478, 746 (1896); Cornell v. Seddinger, 237 Pa. 389, 85 Atl. 446 (1912). 
the duties inseparably attached to his office. But while there has been much preaching about the fiduciary character of the director's office, the great trust and confidence invested in it by shareholders and others, and the sacred duty resting upon directors not to betray their trust and to discharge their duties well, non-participation in the issuance of a prospectus or circular has been for directors a quite invulnerable armor against civil liability. And, in general, suits against directors are still among the most difficult to win.

The common law with respect to liability for misrepresentation in the sale of securities has now been set down. ${ }^{51}$ In verbal statement at least, the liability is, for some cases, very severe. As between vendor and purchaser, rescission is generally available for a false statement of material fact without regard to the bona fides, honest belief, or reasonableness of the belief, of the vendor. Where rescission is not appropriate and damages are sought, liability is imposed not absolutely, but for fault. Fault is, however, a technical, legal trademark-a symbol which denotes source, not composition. Even under the most limited doctrine of liability for false statement, that requiring actual fraudscienter-the innocent, honest utterer is subject to the risk of liability. For, innocence and honesty must be established long after the event in a court which has no exact means of ascertaining states of mind, memory or conscience, and to the satisfaction of men who are to judge on the

51. Mention should be made of three legislative attempts to protect investors. The Blue Sky Laws which have been enacted in almost all the states are discussed elsewhere in this issue. McIntyre, supra note 44. These laws do not enlarge upon the common-law liability for false statement. Typically, they require the licensing of brokers and registration of proposed security issues. Violation of the laws by sales without license or registration renders the sales voidable and there are many instances, in the reports, of the rescission of sales for such violations. Some of the acts permit an action against the directors and officers of the seller who "knowingly" participated in such a sale. But the acts make no provision for civil action by purchasers for misrepresentation in the registration statements. And it has been held that purchasers who bought on the strength of statements filed with a commission pursuant to such laws may not recover for misrepresentation except on the usual common-law grounds; even more, that such statements are not directed to purchasers and that, consequently, purchasers have "no right to rely" on them. See, e. g., Dinsmore v. National Hardwood Co., supra note 46. Moreover, large classes of securities, such as those listed on recognized exchanges, are exempted from the requirements of these laws.

The Post Office Department has authority, by fraud or stop orders, to close the mails to fradulent security-selling schemes. But, obviously, only flagrant frauds are affected by this power.

Under Section 5 of the Federal Trade Commission Act, the Federal Trade Commission has power to enter cease and desist orders in crtain cases of unfair competition. The power has occasionally been exercised to stop false advertising of securities. But clearly the investor has secured little protection from this source. Securities, unlike patent medicines, are not continuously advertised. An entire issue could be sold several times before the Commission could make an investigation and enter its order. 
basis of conflicting evidence and who are entitled not to believe testimony given under the most solemn oath or affirmation. Knowledge, intention and fraud are thus provable by circumstances. And circumstances may damn where conscience is pure. But knowledge of falsity is not required even under the most limited doctrine. It is sufficient if the statement of fact was made as of knowledge when there was no knowledge (of its truth), or that it was made recklessly, careless whether it be true or false, or that it was made without belief in its truth. And lack of investigation by the defendant, carelessness in investigation, or absence of reasonable grounds for the professed belief, are circumstances from which the requisite scienter may be inferred. Finally, in some cases, whether by redefinition of the scienter requirement in the deceit action or by direct extension of the negligence action, a cause of action has been permitted for false statements honestly but negligently made. In the ideal of the law, then, issuers and sellers of securities have lived under very great risks of liability, at least to their immediate vendees. But they have lived well because the reality was not so harsh. Reality was sporting: very few investors brought suit. Reality was indulgent: the men empowered to decide cases made many allowances for the practices of the time. And reality recognized that the ideal required only truth in statement made, not that full statement be made; that sales could be promoted with only scant statement; that troublesome questions could be avoided by omitting mention of a variety of matters and confining circular and prospectus to truthful description of the show window without taking the investor through the store behind it.

Now comes the Securities Act. It requires a picture not simply of the show window, but of the entire store. It requires not simply truth in the statements volunteered, but disclosure. And, for false statement, it provides civil liability. To what extent the lethargy of investors or the indulgence of courts will be affected is unknown. But the ideal of the liability under the Act may be compared with that at common law.

\section{II}

The civil liability provisions of the Act are found in Sections 11 and 12 . The latter section is the lesser of the two and has not evoked much criticism. It provides that (1) "any person" who sells a security as to which a registration statement is not in effect, or who sells a security by the use of a prospectus which does not meet the requirements of Section 10 , shall be liable "to the person purchasing such security from him, who may sue ... to recover the consideration paid for such security with interest thereon, less the amount of any income received thereon, upon the tender of such security, or for damages if he no longer owns the security"; and (2) that the same liability shall be visited upon any person 
who sells a security "by means of a prospectus or oral communication, which includes an untrue statement of a material fact or omits to state a material fact necessary in order to make the statements, in the light of the circumstances under which they were made, not misleading," if the purchaser does not know of the untruth or omission and the seller does not "sustain the burden of proof that he did not know, and in the exercise of reasonable care could not have known, of such untruth or omission."

Neither part of the section puts the seller under a novel, indeterminate or harsh risk. The liability is imposed in favor of the immediate vendee only. Once it is determined that registration and prospectus are necessary, it cannot be unduly difficult to ascertain whether a registration statement is in effect and what prospectus satisfies the requirements of Section 10. The effective date of the registration is defined in Section 8 ; and the contents of the prospectus, as required in Section 10, are specific portions of the registration statement or such information as the Commission may specifically order. The first part of Section 12 does not deal with the truth or falsity of the representations in the registration statement or prospectus. It puts upon the seller only the burden of ascertaining the existence of a registration statement and the conformity of the prospectus with that statement. The absolute liability thus imposed for the sale of unregistered securities or for the use of nonconforming prospectuses is merely that commonly imposed by state Blue Sky laws for similar violations.

The liability imposed by the second part of Section 12 is less stringent. The seller may avoid it by sustaining the burden of proof that he was excusably ignorant of the untruth or omission in the prospectus. In permitting such a defense to rescission, the Act seems also to be less stringent than the commn law. Common-law doctrine, as generally enunciated, allows the buyer to rescind upon proof merely that the seller made a false statement of fact material to the sale. The seller's ignorance of the falsehood, whether excusable or not, is no defense. This is certainly true with respect to statements made by the seller himself. It is doubtless also true in cases where the seller adopts the prospectus and sends it to talk for him. Query whether it is true where the seller sends the prospectus with the warning: "I take no responsibility for anything stated in the prospectus. It contains pertinent information; but I have no knowledge as to the matters stated therein and make no representations about them." Even if the common-law remedy of rescission does not extend to such a case, its inclusion in Section 12-if it is included to the extent of requiring the seller to prove that in the exercise of reasonable care he could not have acquired such knowledge-is not a revolutionary innovation. On the contrary it is in accord with the tendency in sales generally to put upon the seller the risk of loss from 
false statements in the course of a sale, at least to the point of permitting the buyer to rescind.

The common-law remedy of rescission is limited, however, to cases where restoration of the status quo is effected, where the buyer returns what he received from the seller; whereas Section 12 permits the buyer who has disposed of the security to sue for damages. The amount recoverable is quite obviously the difference between the consideration paid and the amount at which the buyer disposed of the security, less any income received thereon by the buyer,-so that the result is substantially that reached where the buyer returns the security to the seller. ${ }^{52}$ This is innovation, if you like. But the severest critic of the Securities Act could hardly condemn this change if it were effected by independent legislation reforming procedure. For, explanation of the difference in the common law between the buyer's action for rescission and his action for damages must be sought not in logic or principle, but in history. And the historical basis of the difference is procedure. At law the seller's false statement, originally even his fraud, was no defense in an action against the buyer for breach of contract. And the only legal remedy available to the buyer was the action for deceit or breach of warranty. Rescission was available only in equity. It was employed principally where the contract was still executory. The purpose was not merely to secure restoration but to cancel the plaintiff's obligation and enjoin the defendant from suing on it at law. If, in the absence of fraud or breach of a fiduciary relationship, the buyer was seeking simply a money decree, the equity court, it was said, lacked jurisdiction to grant him relief. It was want of equity jurisdiction, not want of equity, which defeated the buyer. Thus, the buyer's substantive right depended upon the court in which the right was sought to be, and could be, enforced. Under modern practice where separate courts of law and equity do not exist and all appropriate relief is available in one court, there seems to be

52. It may be suggested that the section does not in express terms provide for this measure of damages and that it permits an interpretation whereby damages may be awarded in accord with whatever measure is employed at common law. The United States Supreme Court has approved the so-called tort measure, namely, the difference between the amount paid and the market value at the time of delivery to the buyer. Smith v. Bolles, 132 U. S. 125 (1889).

But on a fair reading the section seems hardly susceptible of such an interpretation. The section attempts to place the investor who sold his security in no less favorable position than the one who retained it. See Legis. (1933) 33 Cor. L. REv. 1220, 1228, 1233. Particularly in the case of securities it would seem nonsensical to discriminate for the purposes of Section 12 (2) between the investor who retained his securities and the one who sold them. For, the latter could generally repurchase in the market and destroy the discrimination. The theory of the section is rescission. And the definition of the measure of damages seems to be meant for any suit brought uder it, so that, mutatis mutandis, the section will operate equally on all investors who invoke it. See note 14, supra, and note 60, infra. 
no reasonable basis for differentiating between the buyer who is in a position to return the subject of the sale to the seller and the buyer who has disposed of it, beyond so framing the judgment that the net result achieved for the one will be the same as that achieved for the other. The further differentiation in the earlier day was an incident of a different court organization and a different procedure. The crystallization of that incident at the present day into a rule of substantive law is justifiable only if it is consonant with the considerations of policy which determine the substantive question of liability. Consonance there is, if it is deemed desirable that, as between buyer and seller, the risks incident to false statement inducing the purchase should fall upon the buyer. For, then, the differentiation does limit the seller's liability, even though by a haphazard chance method dependent upon irrelevant considerations. If, however, it is deemed desirable to shift the risk to the seller, then the differentiation results in unjustifiable dissonance between the policy and its administration. For, then, the risk is not shifted and the policy is contravened simply because of an irrelevant chance phenomenon.

It is easy to clothe the phenomenon in a cloak of pertinence which hides its lack of significance. It has been said that when restoration of the status quo is had, no affirmative burden is placed on the defendant, no money is taken from his pocket. He simply loses the advantage of his bargain with the plaintiff. Of this loss he is not to complain, since the false statement was, after all, made by him and since, concededly, both parties acted under mutual mistake of the truth. There is no unfairness, therefore, in simply calling bets off. But where the buyer has disposed of the article and is asking damages, he is seeking to impose an affirmative obligation on the defendant,- - not simply to call bets off and restore the status quo, but to take money out of the defendant's pocket. Illustration with the sale of a horse seems to prove the unfairness of permitting the buyer to win in such a case. If the plaintiff, who bought the horse from the defendant for $\$ 100$ and sold it for $\$ 50$, were permitted to recover $\$ 50$ from the defendant, the latter would be minus the horse and plus $\$ 50$. In effect, he would have sold his horse for $\$ 50$. But non constat that, even with knowledge and disclosure of the truth, the defendant would not have valued the horse for his own use at more than $\$ 50$ or would not have been able to sell it himself at more than $\$ 50$. And the case is not altered by taking, instead of the plaintiff's sale price, a so-called market price; for in the horse case that is a fiction or, at best, a norm of variant prices.

As applied to securities, at least when listed on exchanges, this argument is a cloak of cellophane. No sentimental value attaches to any specific shares. All the shares of an issue are alike. They are readily obtainable in the market. The price at any specific time is reasonably fixed. Whether the plaintiff or the defendant makes the sale at a par- 
ticular time, the price will probably be the same. Whenever the defendant wants the shares to hold for a price rise or investment, he can purchase them in the market. It can make little difference to him whether the plaintiff returns the security, then selling for $\$ 50$, and asks for the $\$ 100$ he paid, or sells the security in the market for $\$ 50$ and asks for the $\$ 50$ difference between the sale and purchase price. In either case, the defendant parts with $\$ 50$. If it is fair to impose liability in the first case, it is equally fair to do so in the second.

Other considerations make this similarity of treatment desirable. As stated earlier, the falsity of a statement respecting securities is generally not so easily discoverable as one respecting commodities. The buyer of securities confronted with a fall in price may not have the means, or may deem it unwise, to carry them longer. He may sell for the purpose of mitigating his loss without knowing of the falsity of the statement made to him. If it is good policy to shift unto the seller the risk of loss resulting from false statements used by him to effect the sale, then this buyer needs to be relieved of the loss fully as much as the buyer whose means were more ample or whose judgment was different. Possible complaint by the seller that the buyer sold too soon is hardly appealing. It is of no greater weight than the complaint, where the buyer has not sold, that he held on too long. It can be assumed that if the seller wished to speculate in the security, he could have done so, regardless of the buyer's conduct. Add the provision immunizing the seller if "he did not know, and in the exercise of reasonable care could not have known" of the untruth or omission, and one is impressed by the leniency rather than the stringency of the liability imposed as compared with that under the common-law doctrine. ${ }^{53}$

The section is silent as to possible time limits on the buyer's conduct after discovery of the false statement. In equity suits for rescission apart from the Act, the defense of laches may be interposed where it is claimed that the buyer did not act with reasonable diligence after discovery of the defect. Section 13 provides that legal action must be brought within two years after such discovery or "after such discovery should have been made by the exercise of reasonable diligence." If If the buyer discovers the untruth one-half year after his purchase, may he

53. The provision evidences the purpose of the Act not to mollycoddle the investor, but to impose upon sellers of securities an affirmative obligation to disclose that which by the exercise of reasonable care they can ascertain. Of course, the duty is instinct with risk that their judgment and the judgments of courts and juries as to what constitutes reasonable care will differ. But that is probably the least of the risks which those who purchase and sell securities encounter.

54. The section provides further that actions under Sections 11 and 12 (1) may not be brought "more, than 10 years after the security was bona fide offered to the public." No maximum limitation is provided for actions under section 12 (2) other than the twoyear period mentioned in the text. 
wait a year or more before tendering the security to the seller or before selling it himself? Or, indeed, may he sell the security after such discovery or must he choose rescission if he would avail himself of the protection given by the section? Moreover, is any notice to the seller necessary, other than the institution of suit for rescission or damages? What the judicial answers to these question will be is conjectural. A short answer to all of them is that, there being nothing in the section to the contrary, the buyer may do what he pleases so long as he brings suit within the stipulated two-year period. In any event, these are minute points of detail which litigation will ultimately settle and which should be mentioned, if at all, with an apology for the pettiness. Of greater importance is the omission from this section of any requirement of proof of reliance by the buyer on the untrue statement and of causal connection between the falsity of the statement and the buyer's loss on the security. But the same omission is made in Section 11 and consideration of this feature, as well as of the significance of the phrase "material fact," will be reserved for the discussion of that section.

It is to the liabilities provided for in Section 11 that the paralysis of security flotation prophesied by some is attributed. That section subjects to liability, with respect to every part of the registration statement, every person who signed the registration statement (Section 6 requires that the statement be signed by the issuer, its principal executive, financial and accounting officers and a majority of the board of directors); every person who was a director at the time of filing; every person who is named in the statement as about to become a director; and every underwriter. Experts who are named in the statement as having prepared or certified a part of the statement or a report or valuation which is used in connection therewith are subjected to liability only with respect to the part of the statement, report or valuation which purports to have been prepared or certified by them. The condition of liability is that a "part of the registration statement, when such part became effective, contained an untrue statement of a material fact or omitted to state a material fact required to be stated therein or necessary to make the statements therein not misleading." The right of action is given to "any person acquiring such security," who, as under Section 12, may sue "either ... [1] to recover the consideration paid for such security with interest thereon, less the amount of any income received thereon, upon the tender of such security, or [2] for damages if he no longer owns the security." But "in no case" may "the amount recoverable under this section exceed the price at which the security was offered to the public."

55. $\S 11(\mathrm{~g})$. Literally, this is a limitation on the amount of the judgment in any case and not a measure by which that amount is to be determined. If so interpreted, the purchaser who bought at $\$ 150$ and sold at $\$ 25$, the offering price being $\$ 100$, could recover $\$ 100$, not $\$ 75$. Commissioner Landis has stated that, under his interpretation, the recovery 
The liability of the issuer is almost absolute. The only defense given him is that the plaintiff, at the time of his acquisition of the security, knew of the untruth or omission. ${ }^{56}$ Every other person who is subject to liability may avoid it by sustaining the burden of proof that, upon reasonable investigation he had reasonable ground to believe and did believe at the time the registration statement became effective, that the challenged statements were true and that there was no omission of a material fact required to be stated therein or necessary to make the statements therein not misleading. ${ }^{57}$ The standard of reasonableness by which this defense is to be measured is "that required of a person occupying a fiduciary relationship., 158

In an accompanying article, the definition of the persons thus subjected to liability is scrutinously discussed ${ }^{59}$ Our present concern is with the grounds and extent of the liability. In several important particulars the Acts departs from the common-law civil liability. (1) A purchaser of securities may sue the persons named even though he purchased in the market after the securities had gone through several hands. (2) He may sue even though he never read or knew of the untrue or misleading statement prior to his purchase. (3) He need not establish a causal connection between the untruth and his loss, nor is he barred if such causal connection be disproved. (4) Scienter and its variations are definitely supplanted by the notions of insufficient investigation and unreasonable grounds for belief; and the standard of reasonableness is, not that of "the ordinary, prudent man under the circumstances," but that required of a fiduciary. (5) The burden is on the defendant to establish the reasonableness of his investigation and belief, rather than on the plaintiff to establish the contrary. (6) A measure of damages different in some respects from that under the common law is provided. ${ }^{00}$

would be limited to $\$ 75$. See Douglas and Bates, The Federal Securities Act of 1933 (1933) 43 YaLE L. J. 171, 175. This interpretation is proper if it is borne in mind that the theory of the liability is that of rescission and that the Act attempts to place in the same position both the investor who retained his securities and the investor who sold them.

56. He has, of course, in addition, the defense that the plaintiff has not made out his case by proving that the statement was false, that it related to fact and that the fact was material.

57. An expert may also avoid liability by showing that the part of the registration statement involved "was not a fair copy of or extract from his report or valuation as an expert." "As regards any part of the registration statement purporting to be made on the authority of an expert (other than himself) or purporting to be a copy of or extract from a report or valuation of an expert (other than himself)," the defendant may avoid liability by showing merely that "he had reasonable ground to believe and did believe," and that the statement "fairly represented" the statement of the expert. The burden of the defense is similarly lightened with respect to any part of the registration statement "purporting to be a statement made by an official person or purporting to be a copy of or extract from a public or official document." See also note 56 , supra.

58. $\S 11(\mathrm{c})$.

59. Douglas and Bates, supra note 55 .

60. It is said that two conflicting measures of damages have been developed at common 
On the other hand, conceptions familiar in the common law are retained. (1) The untruth must relate to a matter of "fact" as distinguished, presumably, from one of "opinion." (2) The fact must be a material one. (3) The burden is on the plaintiff to establish, in addition, that the statement was untrue or misleading.

The most striking innovation is, of course, that dispensing with any requirement of privity and permitting "any person acquiring" the security to sue the persons enumerated. To this provision are incident the second and third features mentioned which dispense with the requirement of proof of reliance or causation. ${ }^{61}$ For these incidents, there is ample justification if the desirability of the principal object be assumed. Administratively, reliance and causation are very troublesome subjects of inquiry. Whether the plaintiff read or knew of the statement and whether he relied upon it in making his purchase, are questions rarely, if ever, subject to exact answer. The plaintiff himself can rarely identify the individual factors which influenced his judgment. If proof of reliance is required, he can be trusted in any case, with or without advice of counsel, to allege and testify that he did rely. The question of reliance tends to merge with that of materiality and the answer to the latter is generally also the answer to the former. The plaintiff's assertion that he relied upon the statement, unless taken on faith, will be believed if it appears reasonable that such reliance was had. If the statement relates to something trifling or inconsequential, an inference that reliance was placed upon it seems unreasonable. If it relates to something

law, and jurisdictions have been frequently classified accordingly: (1) the so-called tort measure, which is the difference between the purchase price and the market value at the time of delivery; (2) the so-called warranty measure, which is the difference between the value as represented and the actual (or market) value at the time of delivery. The one, it is said, makes the plaintiff whole; the other gives him the benefit of his expected bargain. Nash v. Minnesota Title Insurance \& Trust Co., 163 Mass. 574, 40 N. E. 1039 (1895) ; McNulty v. Whitney, 273 Mass. 494, 174 N. E. 121 (1930); Reno v. Bull, 226 N. Y. 546, 124 N. E. 144 (1919). But these are generalizations which were not developed with reference to securities specificially. And they are only generalizations. "Varying circumstances," said the New York Court of Appeals, "must logically require variation in the application of that measure of damages. In Reno v. Bull, supra, we applied that measure of damages in the case of a sale of corporate stock where there were no extraordinary features. We did not hold that other cases might not require a different application of the rule." Hotaling $v$. A. B. Leach \& Co., supra note 44 , at $88,159 \mathrm{~N}$. E. at 871 . And, though apparently wedded under Reno $v$. Bull to the tort measure, the court allowed recovery measured neither by the tort nor by the warranty rule, but by the difference between the purchase price and the price at which the plaintifi sold his security. Under Sections 11 and 12 as interpreted by Commissioner Landis, this measure alone must be applied. See notes $\mathbf{5 2}$ and 55 , supria.

61. The English Companies Act, $19 \& 20$ GEo. V, c. 23, \& 37 (1929), provides for liability in favor of "all persons who subscribe for any shares or debentures on the faith of the prospectus for the loss or damage they may have sustained by reason of any untrue statements therein ..." 
material or important, the inference seems reasonable and supports the plaintiff's assertion. The inquiries are merged, then, in the question, Was the statement material? Section 11 puts the plaintiff under the burden of establishing materiality. If it is desirable to extend the liability beyond the parties in privity of contract or sale, there seems to be little point in requiring proof of reliance in addition to that of materiality. Granted that in some cases materiality and reliance can be separated and that the plaintiff's claim might be defeated for lack of the latter, the gain in point of judicial administration is probably worth the loss in prejudice to some defendants. Moreover, requirement of proof of reliance would not mitigate the liability in any determinate amount. It would simply provide a talking point in litigation, with the outcome entirely conjectural. The risks of liability would consequently be substantially the same. The absence of the requirement, whatever bearing it may have on the issue of fairness in particular litigations, can hardly be advanced as ground for the claim that the Act makes the flotation of securities unduly burdensome.

Even more ample justification exists for the omission of the requirement of causal connection between the untruth and the loss. If it be assumed that the untruth related to a fact, material even at the time of the issue rather than at the time of plaintiff's purchase, an inquiry into the causal relation would involve a difficult and inconclusive excursion into philosophical conceptions and imponderables. It is easy to assume in argument that the decline in the price of a security was due so much to economic and other factors unconnected with the untruth and so much, or not at all, to the untruth itself. But to prove the assumption by convincing evidence at a trial months or years after the event would seem well-nigh impossible. Whether the market had or had not discounted the untruth in valuing the security would seem to be a matter for anyone's guess. Philosophically, it can be said that the untruth is always a cause of the plaintiff's loss. No one can say with exactitude what chain of circumstances would have ensued had the untrue statement not been made. In rescission at common law, causation is not a requirement. It appears in actions for deceit, breach of warranty or negligence. When applied in cases involving commodities as to which there is some classification of grades, as, for example, grade A and grade B milk, or in cases of personal injuries alleged to have been caused by defective commodities, inquiry into the causal relations between the misrepresentation of the grade or quality and the loss incurred by the plaintiff may be pursued with some reason and success. But in security cases, where each issue is unique, where there can be no classification of grade in any issue, it would seem to be a hopeless and unreasonable task to make a similar inquiry. The liability under Section 11 is modelled after that in rescission. It makes judicial administration comparatively easy. Again it may be said that the requirement of proof of 
cause would not mitigate the risk of liability by any determinate amount, but would simply provide a talking point for litigants. The gain in administration may itself be worth the attendant prejudice to some defendants. And finally, the causation element is not really entirely banished. Banished in name it is, but not entirely in effect. To a large extent it is instinct in the element of materiality.

The principal innovation mentioned cannot be discussed without constant regard for the purpose of the Act to prevent the occasions for imposition of liability rather than to provide for such liability. That substantial risks are created cannot be denied. But their magnitude is easily overemphasized. Abstractly, there is no limit to the liability. If each share of an issue were to be traded in many times at prices which fluctuated sharply up and down, and each purchaser of the security who sustained a loss were to bring suit, no limit would exist other than the patience, skill and endurance of the most skillful mathematician. But this is in the world of nightmares. In reality there is no such monster. If experience is any kind of a teacher, we can confidently expect that most investors will not bring suit. In the first place, litigation in America is too expensive. The investor who has sustained a small loss would only be sending good money after bad, even if victory were assured. In the second place, while it is easy to assume for discussion an untrue or misleading statement, discovery and proof of it by the investor is an entirely different and incomparably more difficult and expensive task. It is to be remembered that no representative action is provided nor is any agency established for the bringing of a collective suit. Each investor must sue separately. Each must become aware of the untruth and have the means of verifying it. In the third place, the liability is not absolute. In addition to the defenses that the statement referred to opinion rather than fact, that it was literally true rather than false, that it was innocently ambiguous rather than actively misleading, that it was unimportant rather than material-defenses which in commonlaw actions afforded broad avenues for escape,- - the defendants other than the issuer may avoid liability by showing that they had a reasonably grounded belief in the truth of the statement. It has been seen that in the common-law actions lack of reasonable ground for belief, when not recognized directly as a basis of liability, was treated as evidence of scienter, fraud or knowledge of falsity. The risks of liability under these formulae have not kept the persons named in Section 11, upon whom these risks rested, from engaging in their occupations and have not eliminated prosperity from their occupations. Reasonable care is a plastic concept which has been adapted to specific cases without undue hardship to defendants. It would be strange, indeed, if, in cases under the Securities Act, human judgment of reasonableness would become warped. The Act does place the burden of proof on the defendant and defines the standard of reasonableness in terms of that required of a 
fiduciary. But the defendants are in the best position to know what their conduct was and to explain it. And the risks of liability resting upon fiduciaries have not prevented men from assuming the management of large trusts, even though their possible liabilities were out of all proportion to their actual emoluments. ${ }^{62}$ The standard of care required of a fiduciary is merely a verbal formula. It is quite as plastic as the formula "reasonable care under the circumstances." In many phases of corporation law directors are said to be fiduciaries or subject to liability for failure to exercise reasonable care in their supervision. ${ }^{84}$ Yet the director's office has not been regarded as an unduly hazardous one.

The difference is, of course, that the Act has extended the reach of duty. It denies the defense available at common law that the defendant was under no duty to the plaintiff, a person with whom he was not in the relation of privity of contract, to use any amount of care in his conduct, other than to refrain from fraudulently deceiving him. Assuming that the legal difference between fraud and negligence as bases of liability is reasonably clear-an assumption which, as we have seen, is not justified by some cases prior to the Act, - the extension of the duty to cover negligence as well as fraud is in accord with the general "assault upon the citadel of privity" that judges have been making for some time without legislation. In the Touche, Niven case, ${ }^{65}$ some of the judges were willing retroactively to subject accountants to a liability similar to that under the Act, without the help of legislation and without previous specific warning. Had they been sitting on the "court of ultimate error," rather than on those of primary or intermediate error, their opinion would have prevailed. The decision would probably have been adversely criticized by some but it would not have been an unusual step in the evolution of judge-made law.

The severer liability imposed on the issuer is quite analogous to that imposed upon manufacturers and commodity trademark owners in personal injury cases, and with some more reason. The commodity manufacturer's liability has no relation, and is out of all proportion, to the

62. See, e. g., Doyle v. Chatham \& Phoenix National Bank, 253 N. Y. 369, 171 N. E. $574(1930)$.

63. The American Law Institute Restatement of the Iaw of Trusts, Draft T. No. 2 (1931), defines the standard of care required of a fiduciary thus: "Section 169. The trustee is under a duty to the beneficiary in administering the trust to exercise such care and skill as a man of ordinary prudence would exercise in dealing with his own property; and if the trustee has greater skill than that of a man of ordinary prudence, he is under a duty to exercise such skill as he has."

64. See McCormick v. King, 241 Fed. 737 (C. C. A. 9th, 1917); Chapple v. Jacobson, 234 Mich. 558, 208 N. W. 754 (1926); Hun v. Carey, 82 N. Y. 65 (1880); Berle, For Whom Corporate Managers Are Trustees (1932) 45 HARv. L. REv. 1365.

65. Supra note 24. 
price he received for the specific commodity which caused damage. The issuer's liability is limited in any case to the price at which the security was offered to the public, substantially the amount received by him.

With respect to the issuance of securities, a great hazard is imposed on the institution of inactive or dummy directors, a hazard which, it is prophesied by some, will abolish that institution at least in the course of issue. Whether the institution is worth preserving at all or in this particular, is a question of policy which cannot here be discussed. But with respect to active directors and principal officers the requirement imposed is that only of reasonable diligence in the performance of work which involves risks of loss to others. The risk of liability is no greater and perhaps even more justifiable than that imposed upon experts for untrue or misleading statements in their reports. As suggested elsewhere, provision can probably be made by private contract for indemnification of directors and officers by the issuer. ${ }^{66}$ The risks would then be reduced to those of secondary liability.

\section{III}

We can close as we began. The civil liability provisions of the Act are important; but they are not to be overemphasized at the expense of the major purposes of the Act. Civil liability is imposed partly for the purpose of compensating investors, partly, and probably more, for the purpose of compelling compliance with the Act so as to avoid certain types of losses and the need of compensation. Administrative machinery is set up to facilitate compliance. Certainty about every conceivable detail cannot be expected-not any more from this Act than from any other piece of legislation, not any more from the law than from the numerous other institutions which the security business encounters. There may be question as to the wisdom of requiring disclosure of certain matters. There may be ambiguity or obscurity as to the standing or classification of some persons under the Act, although the standing of those major in number and importance is beyond even factitious dispute. There may be doubt as to the wisdom of requiring all directors to take an active precautionary interest in issue work. There may be concern about the incidence of liability upon certain persons whose position may be such as not to warrant it. And there may doubtless be need or desire for further legislation. Studies directed to such specific matters will aid in the building of the structure for which the Act lays the foundation. But it is misleading to focus on the civil lability. Once the policy questions as to the objectives of the Act are answered, there is little in the civil liability provsions which, in a less scientific and less systematic manner, could not or would not have been quietly developed over a period of years by courts on the basis of their own common-law precedents.

66. Douglas and Bates, supra note 55 , at 178 . 